

\section{Examples of Wind Energy Curtailment Practices}

\section{July 2010}

Jennifer Rogers, Sari Fink, and Kevin Porter Exeter Associates, Inc.

Columbia, Maryland

NREL Technical Monitor: Erik Ela

Prepared under Subcontract No. LAM-9-99431-01

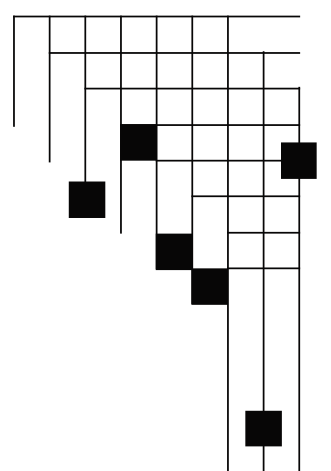




\section{NOTICE}

This report was prepared as an account of work sponsored by an agency of the United States government. Neither the United States government nor any agency thereof, nor any of their employees, makes any warranty, express or implied, or assumes any legal liability or responsibility for the accuracy, completeness, or usefulness of any information, apparatus, product, or process disclosed, or represents that its use would not infringe privately owned rights. Reference herein to any specific commercial product, process, or service by trade name, trademark, manufacturer, or otherwise does not necessarily constitute or imply its endorsement, recommendation, or favoring by the United States government or any agency thereof. The views and opinions of authors expressed herein do not necessarily state or reflect those of the United States government or any agency thereof.

Available electronically at http://www.osti.gov/bridge

Available for a processing fee to U.S. Department of Energy and its contractors, in paper, from:

U.S. Department of Energy

Office of Scientific and Technical Information

P.O. Box 62

Oak Ridge, TN 37831-0062

phone: 865.576 .8401

fax: 865.576 .5728

email: mailto:reports@adonis.osti.gov

Available for sale to the public, in paper, from:

U.S. Department of Commerce

National Technical Information Service

5285 Port Royal Road

Springfield, VA 22161

phone: 800.553 .6847

fax: 703.605.6900

email: orders@ntis.fedworld.gov

online ordering: http://www.ntis.gov/ordering.htm

This publication received minimal editorial review at NREL 


\title{
Examples of Wind Energy Curtailment Practices
}

\author{
Compiled by Jennifer Rogers, Sari Fink and Kevin Porter \\ Exeter Associates, Inc. \\ July 2010
}

and incorporating review comments from:

Jacques Duchesne, Alberta Electric System Operator (AESO)

Alberto Ceña and Miguel Ángel Galán Peña, Asociación Empresarial Eólica

Bart McManus, Bonneville Power Administration (BPA)

Jonathan O'Sullivan and Frank Groome, EirGrid

David Maggio, Electricity Reliability Council of Texas (ERCOT)

Lisa Dangelmaier, Hawaii Electric Co.

Michael McMullen, Midwest Independent System Operator (Midwest ISO)

Erik Ela, Michael Jacobs, and Yih-Huei Wan, National Renewable Energy Laboratory (NREL)

David Edelson, New York Independent System Operator (NYISO)

Dave Souder and Sanjay Patil, PJM

Barry Gilman, Southern California Edison (SCE)

Niels Ehlers, Technische Universität Berlin - Department of Energy Systems

Graeme Ancell, Transpower New Zealand

Drake Bartlett, Xcel Energy

\begin{abstract}
The following table addresses examples of wind energy curtailment practices internationally and in regions across the United States. Examples included from the United States consist of ERCOT, Midwest ISO, New York ISO, PJM, Bonneville Power Administration (BPA), Hawaiian Electric Company, Xcel Energy, and Southern California Edison. Also included are the practices of Ireland, New Zealand, Spain, Germany, and Canada's Alberta province. Table entries are organized as follows:
\end{abstract}

- A description of how wind curtailment is determined;

- $\quad$ Details of the constrained operation procedures;

- The amount of wind curtailed in recent years; and

- What compensation to wind generators is given for curtailment, if any. 


\begin{tabular}{|c|c|c|c|c|}
\hline & Description & Curtailment Procedures & Amount Curtailed & Compensation \\
\hline $\begin{array}{l}\text { Bonneville } \\
\text { Power } \\
\text { Administration }\end{array}$ & $\begin{array}{l}\text { Curtailment procedures for system events } \\
\text { included in large generation interconnection } \\
\text { agreements for wind projects. Wind plants } \\
\text { required to submit schedules based on the most } \\
\text { accurate wind forecast they have available and } \\
\text { be able to accept electronic base-point signals. }\end{array}$ & $\begin{array}{l}\text { When } 90 \% \text { of BPA's balancing reserves are } \\
\text { deployed, BPA requires wind generators to } \\
\text { reduce generation to their scheduled amount } \\
\text { plus their in-hour balancing reserve allocation if } \\
\text { they are generating over this amount. If they } \\
\text { are generating less than their schedule plus } \\
\text { reserve allocation, BPA will curtail schedules to } \\
\text { that value once } 90 \% \text { of the incremental } \\
\text { balancing reserves are deployed. Subject to } \\
\text { certain conditions, BPA may require wind } \\
\text { generator to receive generation limits from } \\
\text { BPA's energy management system if a wind } \\
\text { project does not reach a BPA-specified } \\
\text { generation limit three times in } 24 \text { months. } \\
\text { Wind plants must respond to electronic } \\
\text { basepoint signals within } 10 \text { minutes or BPA can } \\
\text { disconnect the plant. }\end{array}$ & $\begin{array}{l}\text { As of March } 30,2010 \text {, the } \\
\text { estimated total amount of } \\
\text { wind limited was } 2900 \mathrm{MW} \text {, } \\
\text { representing approximately } \\
1000 \mathrm{MWh} \text {. (The MWh } \\
\text { amount is a complete } \\
\text { approximation, as these } \\
\text { events may occur anytime } \\
\text { during the hour.) }\end{array}$ & No compensation. \\
\hline ERCOT & $\begin{array}{l}\text { Congestion is currently managed by ERCOT on a } \\
\text { zonal basis. The majority of wind is located in the } \\
\text { west zone; however, ERCOT is beginning to see a } \\
\text { significant number of wind MWs in the coastal } \\
\text { region. ERCOT previously had special rules } \\
\text { utilizing daily operating limits for wind plants for } \\
\text { the western zone as transmission constraints } \\
\text { limited transfers from the west to the load } \\
\text { centers in central and eastern Texas. The special } \\
\text { rules were removed, however ERCOT continues } \\
\text { to curtail wind plants for congestion purposes. } \\
\text { In ERCOT's new nodal system, wind plants will be } \\
\text { incorporated into economic dispatch and treated } \\
\text { like all other generators. Wind facilities will be } \\
\text { required to respond to electronic signals setting } \\
\text { dispatched generation base-points when needed } \\
\text { for congestion or when the resource appears not } \\
\text { to be economical. }\end{array}$ & $\begin{array}{l}\text { ERCOT may call upon wind plants (and other } \\
\text { generators) to make reductions in output } \\
\text { during periods of transmission congestion. This } \\
\text { will continue to be the case in ERCOT's new } \\
\text { nodal market that will be implemented by the } \\
\text { end of } 2010 \text {. }\end{array}$ & $\begin{array}{l}\text { January to August } 2008 \text {, } \\
\text { curtailed approximately } 140- \\
150 \text { MW about } 45-50 \% \text { of the } \\
\text { days, via restricted daily } \\
\text { operating limits. From } \\
\text { December } 2008 \text { to December } \\
2009 \text {, curtailed between } 500 \\
\text { MW and } 2000 \text { MW daily, and } \\
\text { at times curtailing up to } 3900 \\
\text { MW, but at other times } \\
\text { curtailing } 0 \text { MW. In } 2009 \text {, } \\
\text { average annual wind } \\
\text { curtailment was around } 16 \% \text {. } \\
\text { Monthly averages ranged } \\
\text { from about } 24-28 \% \text { of } \\
\text { potential wind generation } \\
\text { from February-April, to about } \\
6 \% \text { in December, ranging } \\
\text { between } 10-18 \% \text { in January } \\
\text { and from May-November. }\end{array}$ & $\begin{array}{l}\text { If wind plants were } \\
\text { called upon for } \\
\text { curtailment beyond } \\
\text { the daily operating } \\
\text { limits, then ERCOT } \\
\text { paid out-of-merit } \\
\text { energy payments. } \\
\text { Under the nodal } \\
\text { market system, wind } \\
\text { plants will be treated } \\
\text { the same as all } \\
\text { generator types. }\end{array}$ \\
\hline
\end{tabular}




\begin{tabular}{|c|c|c|c|c|}
\hline & Description & Curtailment Procedures & Amount Curtailed & Compensation \\
\hline $\begin{array}{l}\text { Hawaiian } \\
\text { Electric } \\
\text { Company }\end{array}$ & $\begin{array}{l}\text { All wind plants are equipped with curtailment } \\
\text { interfaces controlled by the grid operator. } \\
\text { Electronic base-point generation limits are set by } \\
\text { the grid operator as necessary. }\end{array}$ & $\begin{array}{l}\text { During system emergency events, the grid } \\
\text { operator will use most effective control to } \\
\text { address the issue (such as reducing a specific } \\
\text { wind plant output). During light load times, } \\
\text { must-run generators are reduced to minimum } \\
\text { levels, then as-available generators (including } \\
\text { wind) curtailed according to a pre-determined } \\
\text { priority established via contractual agreements. }\end{array}$ & No data available. & $\begin{array}{l}\text { No additional } \\
\text { compensation; } \\
\text { curtailments built } \\
\text { into contractual } \\
\text { agreements. }\end{array}$ \\
\hline Midwest ISO & $\begin{array}{l}\text { Will curtail variable generation during Minimum } \\
\text { Generation Events after using the emergency } \\
\text { range (between energy minimum and energy } \\
\text { maximum) of conventional generation. } \\
\text { Transmission constraints may lead to wind } \\
\text { curtailments if market redispatch of } \\
\text { conventional generation is not sufficient to } \\
\text { relieve the constraint. Curtailment order is based } \\
\text { on impact on the constraint and transmission } \\
\text { service priority. }\end{array}$ & $\begin{array}{l}\text { During Minimum Generation Events, Midwest } \\
\text { ISO orders curtailments in the following order: } \\
\text { 1. Generation identified through the Reliability } \\
\text { Assessment Commitment process. } \\
\text { 2. Variable generation above its Day-Ahead } \\
\text { Schedule } \\
\text { 3. With emphasis placed on shortest turn- } \\
\text { around time (shut down and re-start) and } \\
\text { reverse economic order, generation will be } \\
\text { decomitted as necessary to maintain balance } \\
\text { of load and generation. }\end{array}$ & $\begin{array}{l}\text { In } 2009 \text {, the Midwest ISO } \\
\text { curtailed wind due to } \\
\text { transmission constraints } 10 \text { to } \\
170 \text { times each month, } \\
\text { totaling about } 1,100 \text { wind } \\
\text { curtailments for the year. } \\
\text { About } 200,000 \text { MWh were } \\
\text { curtailed in } 2009 \text {. } \\
\text { In } 2009 \text {, average wind } \\
\text { curtailment was about } 1 \% \text { of } \\
\text { wind generation, with } \\
\text { monthly averages ranging } \\
\text { from about } 0.07 \% \text { to } 2.86 \% \text { of } \\
\text { potential monthly wind } \\
\text { generation. } \\
\text { The Midwest ISO curtailed } \\
\text { intermittent resources once } \\
\text { during Minimum Generation } \\
\text { Events in } 2009 \text {. }\end{array}$ & $\begin{array}{l}\text { No additional } \\
\text { compensation from } \\
\text { Midwest ISO. Certain } \\
\text { utilities in the } \\
\text { Midwest ISO may } \\
\text { have compensation } \\
\text { programs for } \\
\text { curtailing wind } \\
\text { energy. }\end{array}$ \\
\hline
\end{tabular}




\begin{tabular}{|c|c|c|c|c|}
\hline & Description & Curtailment Procedures & Amount Curtailed & Compensation \\
\hline PJM & $\begin{array}{l}\text { Wind included in procedures for Transmission } \\
\text { Constraints and Light Load Events. Wind } \\
\text { curtailed along with other generation based on } \\
\$ / M W \text { effect for transmission constraints and } \\
\text { economic bid for Light Load Events. Wind } \\
\text { assumed to have emergency minimum of zero } \\
\text { unless otherwise bid. Wind plants are required } \\
\text { to be modeled by wind power forecasting } \\
\text { services and be able to accept electronic base- } \\
\text { point signals. }\end{array}$ & $\begin{array}{l}\text { During events, all generation reduced to } \\
\text { economic minimum first. If additional } \\
\text { curtailment needed, all generation reduced to } \\
\text { emergency minimum levels. Wind plants are } \\
\text { required to respond to electronic base-point } \\
\text { dispatch signals within } 15 \text { minutes or must } \\
\text { notify PJM if they cannot respond that quickly. }\end{array}$ & No data available. & $\begin{array}{l}\text { No additional } \\
\text { compensation. }\end{array}$ \\
\hline New York ISO & $\begin{array}{l}\text { Wind integrated into real-time and day-ahead } \\
\text { market dispatch. Wind bids a price-quantity } \\
\text { curve into the real-time market and is } \\
\text { dispatched economically along with other } \\
\text { generation. Wind plants must participate in wind } \\
\text { forecasting and be able to accept electronic } \\
\text { base-point dispatch signals. }\end{array}$ & $\begin{array}{l}\text { During constrained operations, generation will } \\
\text { be curtailed according to economic bids. Wind } \\
\text { plants must follow electronic base-point } \\
\text { dispatch signals within } 5 \text { minutes or be assessed } \\
\text { penalties for non-compliance. }\end{array}$ & No data available. & $\begin{array}{l}\text { No additional } \\
\text { compensation. }\end{array}$ \\
\hline $\begin{array}{l}\text { Southern } \\
\text { California } \\
\text { Edison }\end{array}$ & $\begin{array}{l}\text { Wind curtailment may occur in the Tehachapi } \\
\text { region due to transmission constraints. SCE's } \\
\text { request to curtail wind under certain conditions } \\
\text { is pending before the California PUC. }\end{array}$ & $\begin{array}{l}\text { Agreement with Terra-Gen Power to reduce } \\
\text { output on an as-needed basis. }\end{array}$ & $\begin{array}{l}\text { About } 15 \mathrm{MW} \text { for } 3-4 \text { hours } \\
\text { about every two days (or } 6-8 \% \\
\text { of the time). }\end{array}$ & $\begin{array}{l}\text { Make whole } \\
\text { payment for energy. }\end{array}$ \\
\hline
\end{tabular}




\begin{tabular}{|c|c|c|c|c|}
\hline & Description & Curtailment Procedures & Amount Curtailed & Compensation \\
\hline Xcel Energy & $\begin{array}{l}\text { Northern States Power MN (NSP) is in the } \\
\text { Midwest ISO and follows the Midwest ISO's } \\
\text { direction on whether curtailment is required. } \\
\text { Public Service of Colorado (PSCO) and } \\
\text { Southwestern Public Service (SPS) have } \\
\text { procedures to reduce all generation and } \\
\text { prices/sales to minimum levels prior to ordering } \\
\text { wind energy curtailments. }\end{array}$ & $\begin{array}{l}\text { NSP: agreements with wind plants in Southwest } \\
\text { Minnesota to curtail on a rotational basis when } \\
\text { required by Midwest ISO. } \\
\text { PSCO: contracts with certain wind plants to } \\
\text { curtail a set amount per year on an as-needed } \\
\text { basis. If additional curtailment required, PSCO } \\
\text { will call wind plants to curtail on a rotational } \\
\text { basis. } \\
\text { SPS: call wind plants to curtail on a rotational } \\
\text { basis. }\end{array}$ & $\begin{array}{l}\text { NSP: } \\
\text { 2007: 112,244 MWh } \\
\text { 2008: 25,367 MWh } \\
\text { 2009: 42,359 MWh } \\
\text { PSCO: } \\
\text { 2008: 2,464 MWh } \\
\text { 2009: 18,991 MWh } \\
\text { SPS-owned wind resources } \\
\text { have not been curtailed to } \\
\text { date. Data on curtailments of } \\
\text { merchant wind within the SPS } \\
\text { Balancing Authority is } \\
\text { unavailable. }\end{array}$ & $\begin{array}{l}\text { NSP: make whole } \\
\text { kWh payments for } \\
\text { both fixed and } \\
\text { variable costs. } \\
\text { PSCO: contracted } \\
\text { amounts are at no } \\
\text { cost. Additional } \\
\text { amounts made } \\
\text { whole for energy } \\
\text { plus Production Tax } \\
\text { Credit. }\end{array}$ \\
\hline
\end{tabular}




\section{Examples of International Wind Energy Curtailment Practices}

\begin{tabular}{|c|c|c|c|c|}
\hline & Description & Curtailment Procedures & Amount Curtailed & Compensation \\
\hline $\begin{array}{l}\text { Alberta Electric } \\
\text { System } \\
\text { Operator } \\
\text { (AESO) }\end{array}$ & $\begin{array}{l}\text { Wind power curtailment occurs because of } \\
\text { transmission constraints and other } \\
\text { reliability events. }\end{array}$ & $\begin{array}{l}\text { Wind curtailments are based on reliability } \\
\text { concerns. Each wind project may have a } \\
\text { Remedial Action Scheme defined in their } \\
\text { interconnection requirements. }\end{array}$ & $\begin{array}{l}\text { The AESO curtailed wind for } 860 \\
\text { hours in } 2008 \text {, for } 838 \text { hours in } \\
2009 \text {, and for } 236 \text { hours during } \\
\text { the period of January } 2010- \\
\text { March } 2010 \text {. }\end{array}$ & $\begin{array}{l}\text { Wind generators are not } \\
\text { compensated if } \\
\text { curtailed. }\end{array}$ \\
\hline Germany & $\begin{array}{l}\text { Electric power facilities over } 100 \mathrm{~kW} \text { are } \\
\text { subject to generation management. }\end{array}$ & $\begin{array}{l}\text { The distribution grid operator may curtail } \\
\text { wind in the case of congestion in the local } \\
\text { grid. } \\
\text { The transmission service operator (TSO) } \\
\text { must sell all renewable energy on the day- } \\
\text { ahead market but may, under a rule in } \\
\text { effect until the end of 2010, limit its sales } \\
\text { of renewable energy orders for } 100 \text { hours } \\
\text { per half year if the market cannot clear or } \\
\text { extremely negative prices are expected. If } \\
\text { there is some energy that cannot be sold } \\
\text { on the day-ahead market and intra-day } \\
\text { market prices are expected to be lower, the } \\
\text { TSO may use bilateral contracts with the } \\
\text { installation owner and curtail wind. } \\
\text { If congestion is a threat to system reliability } \\
\text { after the above methods have been tried, } \\
\text { the TSO may curtail or shut down wind } \\
\text { installations. }\end{array}$ & $\begin{array}{l}\text { Between } 2004 \text { and } 2006,74 \mathrm{GWh} \\
\text { of wind power were curtailed. }\end{array}$ & $\begin{array}{l}\text { Distribution grid } \\
\text { operators: } \\
\text { compensation } \\
\text { equivalent to lost } \\
\text { revenues. } \\
\text { Transmission service } \\
\text { operator: in the case of } \\
\text { bilateral contracts } \\
\text { (discussed under } \\
\text { 'Curtailment } \\
\text { Procedures'), } \\
\text { compensation } \\
\text { equivalent to lost } \\
\text { revenues. In the case of } \\
\text { a remaining congestion } \\
\text { threat after other } \\
\text { methods have been } \\
\text { attempted, there is no } \\
\text { payment or } \\
\text { compensation for } \\
\text { curtailment. }\end{array}$ \\
\hline New Zealand & Wind is curtailed on a case-by-case basis. & $\begin{array}{l}\text { The system operator sends a dispatch } \\
\text { instruction to the wind generator requiring } \\
\text { output to be reduced to a fixed level. One } \\
\text { wind project has automatic run-back that } \\
\text { limits project output when loading on } \\
\text { certain transmission lines reaches } \\
\text { continuous rating. }\end{array}$ & No data available. & $\begin{array}{l}\text { Wind generators are not } \\
\text { compensated if } \\
\text { curtailed. }\end{array}$ \\
\hline
\end{tabular}




\begin{tabular}{|c|c|c|c|c|}
\hline & Description & Curtailment Procedures & Amount Curtailed & Compensation \\
\hline Ireland & $\begin{array}{l}\text { Wind in Ireland is only curtailed if there is a } \\
\text { system security issue, as members of the } \\
\text { EU are required to grant priority dispatch } \\
\text { to wind. In the event of a system security } \\
\text { issue, dispatch down occurs in the } \\
\text { following order: indigenous peat stations, } \\
\text { large combined heat and power, hydro, } \\
\text { and then wind. This operational practice is } \\
\text { under regulatory review. } \\
\text { In } 2009 \text {, wind was primarily curtailed due } \\
\text { to transmission maintenance occurring in a } \\
\text { high wind area with low load, following the } \\
\text { global financial crisis. New transmission is } \\
\text { under study; however, EirGrid expects wind } \\
\text { will be increasingly dispatched down for } \\
\text { non-congestion reasons. }\end{array}$ & $\begin{array}{l}\text { The control of wind projects is done via } \\
\text { remote control from EirGrid's control } \\
\text { center. Response times occur within } 10 \\
\text { seconds of receipt of the signal to curtail. }\end{array}$ & $\begin{array}{l}\text { Less than } 100 \mathrm{MWh} \text { was curtailed } \\
\text { in } 2008 .\end{array}$ & $\begin{array}{l}\text { Wind generators that } \\
\text { are dispatched down are } \\
\text { paid in the energy } \\
\text { market as if they } \\
\text { generated the full } \\
\text { available output, but } \\
\text { Ireland's support } \\
\text { mechanisms do not } \\
\text { provide compensation in } \\
\text { this case. Therefore, } \\
\text { there are commercial } \\
\text { consequences for wind } \\
\text { that is dispatched down } \\
\text { when the market price is } \\
\text { lower than the } \\
\text { guaranteed support } \\
\text { price. }\end{array}$ \\
\hline Spain & $\begin{array}{l}\text { Wind may be curtailed in Spain for the } \\
\text { following reasons: congestion, net stability, } \\
\text { short-circuit power concerns, inadequate } \\
\text { active/reactive power levels, and minimum } \\
\text { load. } \\
\text { Up until late 2009, the majority of } \\
\text { curtailments were due to problems of } \\
\text { congestion. In late } 2009 \text { and the first three } \\
\text { months of } 2010 \text {, the majority of } \\
\text { curtailments were due to wind generation } \\
\text { being greater than minimum load. } \\
\text { There are two possible curtailments: } \\
\text { - Programmed, before day-ahead market is } \\
\text { closed. } \\
\text { - Real time, in the intraday markets. }\end{array}$ & $\begin{array}{l}\text { The system operator sends curtailment } \\
\text { instructions to the wind farms (in fact, } \\
\text { limits of production) via the Control Centre } \\
\text { for Renewable Energies (CECRE) through } \\
\text { the Generation Control Centers (GCC). } \\
\text { Wind power facilities of } 10 \mathrm{MW} \text { or more } \\
\text { must be directly connected to the GCC, } \\
\text { which are connected to them using an ICCP } \\
\text { protocol. They also must have sufficient } \\
\text { local controls to execute CECRE orders. } \\
\text { These orders are refreshed every } 12 \\
\text { seconds and they should be executed in } 15 \\
\text { minutes. CECRE uses the GEMAS analytical } \\
\text { model to determine need for curtailment } \\
\text { of wind power facilities in case of net } \\
\text { instability risks due to possible sudden } \\
\text { voltage dips. }\end{array}$ & $\begin{array}{l}\text { In } 2007,23.9 \text { GWh of wind } \\
\text { generation was curtailed, which } \\
\text { represented } 0.09 \% \text { of total wind } \\
\text { production. In } 2008, \text { wind } \\
\text { generation curtailments } \\
\text { represented about } 0.3 \% \text { of total } \\
\text { wind production. In } 2009,54 \\
\text { GWh of wind generation was } \\
\text { curtailed, representing about } \\
0.15 \% \text { of total wind production. } \\
\text { In the first three months of } 2010 \text {, } \\
1 \% \text { of wind production was } \\
\text { curtailed with a loss of profits of } \\
\text { around } 10 \text { M€. } \\
\text { Wind power curtailments are } \\
\text { expected to increase in the } \\
\text { future, with the possibility of } \\
\text { rising to as much as } 6.8 \% \text { of total } \\
\text { wind production. }\end{array}$ & $\begin{array}{l}\text { Programmed } \\
\text { curtailments: } \\
\text { wind generators are not } \\
\text { compensated if curtailed } \\
\text { in programmed } \\
\text { curtailments. } \\
\text { Real time curtailments: } \\
\text { they receive a } \\
\text { compensation of about } \\
15 \% \text { of the wholesale } \\
\text { price for each hour } \\
\text { without premium, which } \\
\text { is multiplied by the } \\
\text { theoretical production, } \\
\text { based on the wind } \\
\text { forecasts. }\end{array}$ \\
\hline
\end{tabular}




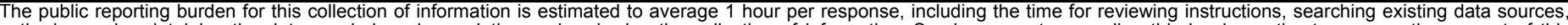

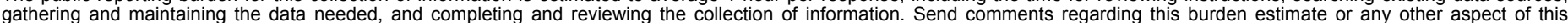

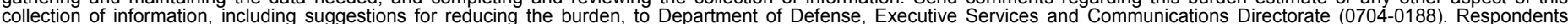

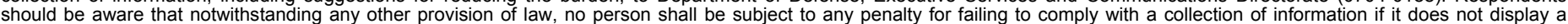

should be aware that notwithstanding

PLEASE DO NOT RETURN YOUR FORM TO THE ABOVE ORGANIZATION.

\begin{tabular}{l|l|l|l} 
1. REPORT DATE (DD-MM-YYYY) & 2. REPORT TYPE & 3. DATES COVERED (FrOm - TO)
\end{tabular}

July 2010

Subcontract Report

4. TITLE AND SUBTITLE

Examples of Wind Energy Curtailment Practices

5a. CONTRACT NUMBER

DE-AC36-08-GO28308

5b. GRANT NUMBER

5c. PROGRAM ELEMENT NUMBER

6. AUTHOR(S)

J. Rogers, S. Fink, and K. Porter

5d. PROJECT NUMBER

NREL/SR-550-48737

5e. TASK NUMBER

WE104311

5f. WORK UNIT NUMBER
7. PERFORMING ORGANIZATION NAME(S) AND ADDRESS(ES)

Exeter Associates, Inc.

10480 Little Patuxent Parkway, Suite 300

Columbia, MD 21044

9. SPONSORING/MONITORING AGENCY NAME(S) AND ADDRESS(ES)

National Renewable Energy Laboratory

1617 Cole Blvd.

Golden, CO 80401-3393
8. PERFORMING ORGANIZATION REPORT NUMBER

LAM-9-99431-01
10. SPONSOR/MONITOR'S ACRONYM(S) NREL

11. SPONSORING/MONITORING AGENCY REPORT NUMBER NREL/SR-550-48737

12. DISTRIBUTION AVAILABILITY STATEMENT

National Technical Information Service

U.S. Department of Commerce

5285 Port Royal Road

Springfield, VA 22161

13. SUPPLEMENTARY NOTES

NREL Technical Monitor: Erik Ela

14. ABSTRACT (Maximum 200 Words)

This report addresses examples of wind energy curtailment practices internationally and in regions across the United States.

\section{SUBJECT TERMS}

Wind; curtailment; ERCOT; BPA; Midwest ISO; New York ISO; PJM; Xcel; Hawaiian Electric Company; SCE; Ireland; New Zealand; Spain; Germany; Alberta; Canada

\begin{tabular}{l} 
16. SECURITY CLASSIFICATION OF: \\
\begin{tabular}{|l|l|l|}
\hline a. REPORT & b. ABSTRACT & c. THIS PAGE \\
Unclassified & Unclassified & Unclassified \\
& & \\
\hline
\end{tabular} \\
\hline
\end{tabular}

\begin{tabular}{l|l} 
17. LIMITATION & 18. NUMBER \\
OF ABSTRACT & OF PAGES \\
UL & \\
& \\
\hline
\end{tabular}

19a. NAME OF RESPONSIBLE PERSON

19b. TELEPHONE NUMBER (Include area code) 